\title{
Analysis of the activation routes induced by different metal oxide nanoparticles on human lung epithelial cells
}

Nanoparticles (Nps) can induce toxicity in the lung by accidental or intentional exposure. The main objective of the study reported here was to characterize the effect that four metal oxide $\mathrm{Nps}\left(\mathrm{CeO}_{2}, \mathrm{TiO}_{2}, \mathrm{Al}_{2} \mathrm{O}_{3}\right.$ and $\left.\mathrm{ZnO}\right)$ had at the cellular level on a human lung epithelial cell line. This goal was achieved by studying the capacity of the Nps to activate the main mitogen-activated protein kinases (MAPKs) and the nuclear factor NF $\mathrm{B}$. Only $\mathrm{ZnO}$ Nps were able to activate all of the MAPKs and the release of $\mathrm{Zn}^{2+}$ ions was the main cause of activation. $\mathrm{ZnO}$ and $\mathrm{Al}_{2} \mathrm{O}_{3} \mathrm{Nps}$ activated the $\mathrm{NF} \kappa \mathrm{B}$ pathway and induced the release of inflammatory cytokines. $\mathrm{CeO}_{2}$ and $\mathrm{TiO}_{2} \mathrm{Nps}$ were found to have safer profiles.

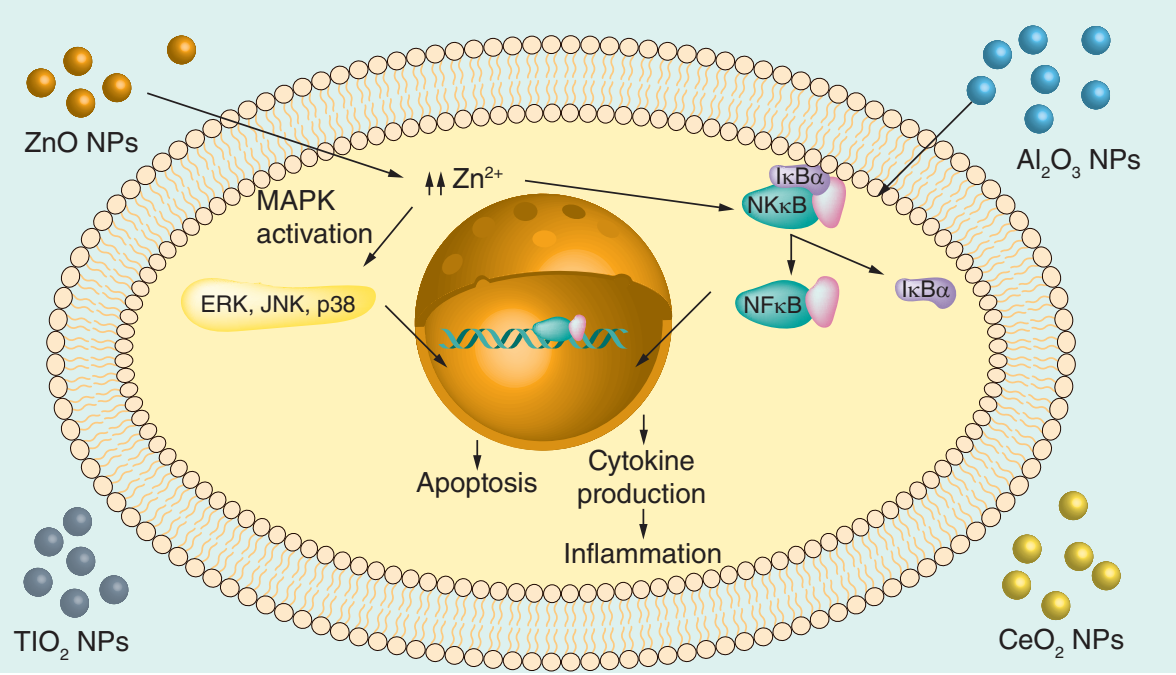

The graphical abstract was obtained using Servier Medical Art.

Lay abstract: When cells are exposed to a stimulus, they can activate different signaling pathways and these lead to different responses such as proliferation, differentiation, migration or inflammation. The objective of the work described here was to characterize the effects of several metal oxide nanoparticles at the cellular level by studying their capacity to activate the main mitogen-activated protein kinases (MAPKs) and the expression of the transcription factor NFKB on a human lung epithelial cell line. These signaling proteins play a relevant role in the vast majority of the cellular events that are triggered in eukaryotic cells after any stimulus.

First draft submitted: 8 October 2015; Accepted for publication 8 January 2016; Published online 15 April 2016

Keywords: cytokines $\bullet$ inflammation $\bullet$ MAPK $\bullet$ metal oxide nanoparticles $\bullet$ NFKB
Rosana Simón-Vázquez**,‡,1, Tamara Lozano-Fernández ${ }^{\ddagger, 1}$, Angela Dávila-Grana \& África González-Fernández*,1 'Immunology, Biomedical Research Center (CINBIO) \& Institute of Biomedical Research of Orense, Pontevedra and Vigo (IBI), University of Vigo, Campus Lagoas Marcosende, Vigo, Pontevedra, 36310 Spain

*Author for correspondence: Tel.: 0034986812625 africa@uvigo.es

**Author for correspondence: Tel.: 0034986812625 rosana.simon@uvigo.es ${ }^{\ddagger}$ Authors contributed equally 


\section{Background}

Nanoparticles (Nps) can reach the lung by intentional administration or accidental exposure, either by inhalation or systemic administration [1]. Accidental inhalation could occur through exposure to nanoparticle aerosols formed during the manufacture, manipulation or packaging of these nanomaterials [2]. The tendency of the Nps to form bigger agglomerates, which can reach the micron size, decreases the risk of inhalation. However, surface modification of the Nps to avoid agglomeration, such as the use of polyethylene glycol or protein binding, decreases the tendency to agglomerate [3]. In addition, the inhaled Nps could reach not only the lung but other organs, including neurons by translocation through the olfactory bulb, or the blood through interstitial translocation, followed by their systemic distribution [3]. In contrast, systemic delivery by injection of the Nps or by absorption following dermal application or ingestion may cause incidental pulmonary exposure [1].

Several toxicological studies on inhaled metal oxide Nps in animals have been carried out and numerous differences between the different animal models were identified for the same type of Nps. For instance, the inhalation of ultrafine $\mathrm{TiO}_{2}$ particles produces different effects in mice, rats and hamsters, with rats affected the most by inflammation, followed by mice and hamsters [4]. The latter group showed a very fast particle clearance compared with the other two species'. In contrast, the results of another study showed that fine and ultrafine $\mathrm{TiO}_{2}$ Nps appear to be safe for mammals and aquatic organisms following acute exposure [5]. Specifically, in vivo pulmonary toxicity studies in rats carried out with the aforementioned Nps demonstrated the low inflammatory potential and low lung tissue toxicity. The results of a different study showed that the subacute inhalation of $\mathrm{TiO}_{2} \mathrm{Nps}$ caused moderate inflammation in mice but this was resolved within 3 weeks [6]. Nevertheless, the murine model is not the most appropriate to describe lung toxicity because significant differences with primates are found in the mechanism of toxicity and, hence, in the outcomes of the exposure [7].

The results of human toxicological studies have shown that sustained exposure to Nps can cause severe inflammation, with pleural effusion, pulmonary fibrosis, granuloma and impairment of the breathing function, as observed in a group of young female Chinese workers accidentally exposed to polyacrylate Nps over several months. As a result of this strong lung dysfunction, two of the workers died shortly after the onset of the disease [8].

Nps entering via the respiratory tract could be responsible for numerous toxicological events. The main underlying cellular mechanisms of $\mathrm{Np}$-induced toxicity are the ineffective clearance of the Nps, oxidative stress and genotoxicity [9]. The increase in levels of the reactive oxygen species' (ROS) could lead to the activation of several signaling pathways, such as the MAPK and the expression of inflammatory cytokines [10-12]. Genes involved in lung inflammation are transcribed as a result of this activation. Npinduced genotoxicity could be responsible for DNA damage in cells and tissues, altered cell cycle kinetics, induced expression of $\mathrm{p} 53$ and DNA repair related proteins, mutagenesis and carcinogenesis processes [13]. Other lung disorders, in addition to inflammation, could be induced by exposure to the Nps and these include fibrosis, pneumoconiosis and exacerbation of asthma [9]. Moreover, an association between the inhalation of particulate matter and an increase in pulmonary and cardiovascular morbidity and mortality has been established [14].

In general, metal oxide Nps have been shown to induce low inflammatory cytokine release in vitro in airway cells (BEAS-2B) compared with particles derived from soil dusts, and they are probably less toxic to the lung [15].

In addition to the well-characterized cytotoxicity, ROS production and genotoxicity, metal oxide Nps may induce other effects on the cells after interaction and/or internalization. As a consequence, characterization of the MAPKs and the NFKB pathways could provide more detailed information and allow discrimination between those Nps that induce some cellular effect and those that are more innocuous.

MAPK and NFKB are well-known signaling proteins that are activated by several extracellular stimuli and they induce a broad spectrum of cellular effects, such as proliferation, differentiation, migration, inflammation and apoptosis, among others.

The specific activation of the three main MAPKs (ERK, p38 and SAP/JNK) and their relation with pathogenic effects are of great interest. For instance, the activation of ERK is mainly related to proliferation while the activation of SAP/JNK is related to apoptosis, as observed with ultrafine carbon particles in rat lung epithelial cells depending on the dose and time [16]. The activation of MAPK is also relevant in the carcinogenesis process in asbestos-induced toxicity in smokers. Both toxins, in other words, cigarette smoke and asbestos, induce the activation of MAPK and the expression of AP-1 transcription factor regulated genes [17].

MAPK signaling can be triggered by activation of tyrosine kinase membrane receptors, such as the EGFR, by ligand binding or by oxidative stress via several different mechanisms [18,19]. 
The NFKB family of transcription factors (TFs) are also key regulators of immune, inflammatory and acute phase responses, and these TFs are also implicated in the control of cell proliferation, apoptosis and oncogenesis [20]. These TFs also play a key role in the induction of pro-inflammatory gene expression, leading to the synthesis of inflammatory cytokines such as IL-6, IL1 $\beta$ and TNF- $\alpha$, chemokines such as IL-8, adhesion molecules such as ICAM-1, growth factors and enzymes [21].

$\mathrm{NF \kappa B}$ plays a major role in common lung diseases associated with a relevant inflammatory component, such as asthma and chronic obstructive pulmonary disease (COPD) [21-23]. In COPD, the activation of $\mathrm{NF \kappa B}$ has been implicated in the pathogenesis, but its exact role is not clear due to the heterogeneity of the patient population. NFKB activation has also been related with mineral dust diseases and it is probably involved in their pathogenesis [21].

Several studies have already been conducted into cellular toxicity induced by metal oxide Nps in different cell types mediated by the activation of those pathways. For instance, it has been shown that $\mathrm{ZnO} N p s$ induce apoptosis by p53-p38 activation in a human dermal fibroblast cell line [24] and $\mathrm{CeO}_{2} \mathrm{Nps}$ are able to induce the activation of the three MAPKs (ERK1/2, p38 and JNK) in a hepatocyte cell line, thus increasing the ROS levels and reducing the viability of the cells [25]. In fact, this activation and the cellular effects were attenuated by using an antioxidant. Similar cellular outcomes were found for silica Nps in HUVECs, a human umbilical vein endothelial cell line, where the activation of JNK, p53 and NFKB was also mediated by oxidative stress, which induces inflammation and apoptosis in the cells exposed to the Nps at a concentration higher than $50 \mu \mathrm{g} / \mathrm{ml}$ [26]. In contrast, $\mathrm{TiO}_{2}-$ activated neutrophils in a concentration-dependent manner mediated by the activation of ERK and $\mathrm{p} 38$. These particles also inhibited apoptosis in a concentration-dependent manner at concentrations of $20 \mu \mathrm{g} /$ $\mathrm{ml}$ or above and, after a long incubation time, they induced the production of several cytokines such as IL-8. In fact, $\mathrm{TiO}_{2}$ Nps exerted several neutrophil agonist functions in vitro [27]. Correspondingly, in a bronchial epithelial cell line $\mathrm{TiO}_{2} \mathrm{Nps}$ also induced the expression of IL-8 and once again this was mediated by the activation of ERK and p38, as determined using inhibitors of these kinases that reduced the expression of this inflammatory cytokine [28]. More recently, this $\mathrm{TiO}_{2}$-mediated IL-8 release was also detected in human colon epithelial cells together with $\mathrm{NF \kappa B}$ activation [29]. The fact that the activation of two different pathways may lead to the same cellular event could be due to crosstalk between them [30]. However, this behavior could also be due to a different triggering event or selection of a different signaling pathway depending on the stimulus, as observed in normal human bronchial epithelial cells incubated with ultrafine carbon particles. The IL- 8 expression induced by these particles was mediated by $\mathrm{p} 38$ and not by NFKB, behavior that has been described previously for those cells [31] and has also been observed with $\mathrm{ZnO}$ Nps [32].

In the study described here, we compared the activation of MAPK and NFKB pathways induced by four different metal oxide $\mathrm{Nps}\left(\mathrm{CeO}_{2}, \mathrm{TiO}_{2}, \mathrm{Al}_{2} \mathrm{O}_{3}\right.$ and $\mathrm{ZnO}$ ) in a non-small-cell lung epithelial cell line: NCI-H460. Two different concentrations per $\mathrm{Np}$ were tested: 10 and $100 \mu \mathrm{g} / \mathrm{ml}$ for $\mathrm{CeO}_{2}, \mathrm{TiO}_{2}$ and $\mathrm{Al}_{2} \mathrm{O}_{3}$ $\mathrm{Nps}$; but only 5 and $50 \mu \mathrm{g} / \mathrm{ml}$ for $\mathrm{ZnO} \mathrm{Nps}$ (due to their high cell toxicity [33]). Due to the association proposed between ion release and the toxicity induced by some metal oxide Nps [12,34-37], the potential effect produced by $\mathrm{Zn}^{2+}$ ions was also evaluated by adding $\mathrm{ZnCl}_{2}$ salt to the cells. Finally, the cytokine release induced by the metal oxide Nps was characterized in human peripheral blood mononuclear cells (PBMCs).

\section{Methods}

\section{Nanoparticle preparation}

The commercial Nps used in this work were supplied by Sergio Moya (CIC-Biomagune, San Sebastian, Spain) as part of the HINAMOX project (7th EU framework program) and they were: $\mathrm{TiO}_{2} \mathrm{Nps}(3.59 \pm$ $0.94 \mathrm{~nm}$, anatase phase) and $\mathrm{Al}_{2} \mathrm{O}_{3} \mathrm{Nps}(13.56 \pm 8.37$ $\mathrm{nm})$ from PlasmaChem (Berlin, Germany); $\mathrm{CeO}_{2} \mathrm{Nps}$ $(13.04 \pm 12.13 \mathrm{~nm})$ and $\mathrm{ZnO}$ Nps $(36.16 \pm 18.27 \mathrm{~nm})$ from Evonik Industries AG (Essen, Germany). The $\mathrm{Np}$ size was determined by TEM and all the Nps were uncoated. The TEM images and DLS characterization in water were described previously [38]. The DLS measurements in culture medium RPMI 1640 from Gibco, Life Technologies (CA, USA) supplemented with $10 \%$ fetal bovine serum (FBS) were performed using a Zetasizer Nano ZS from Malvern Instruments (Worcester, $\mathrm{UK})$ at $25^{\circ} \mathrm{C}$. Suspensions of $\mathrm{Nps}$ at $1 \mathrm{mg} / \mathrm{ml}$ in culture medium were prepared for zeta potential determination. Each sample was measured four-times, with a combination of 200 runs per measurement. For zeta size determination, Nps $(25 \mu \mathrm{g} / \mathrm{ml})$ were suspended in medium and three measurements were averaged, with a combination of 13 runs per measurement. The Np size distribution was determined by intensity.

A stock of Nps was prepared at $10 \mathrm{mg} / \mathrm{ml}$ in milli$\mathrm{Q}$ water and the mixture was sonicated for $10 \mathrm{~min}$ at low frequency $(47 \mathrm{kHz})$ in a Branson 1510 ultrasonic bath (CT, USA). After this time $10 \%$ fetal bovine serum (FBS: PAA Laboratories, Pasching, Austria) was added. Finally, the Nps were diluted to the working 
concentration in RPMI 1640 supplemented with 10\% FBS. The sterility of the Nps was preserved in all cases and for control samples the same amount of water with $10 \%$ FBS was added.

\section{Cell viability assay: $x$ CELLigence ${ }^{\circledR}$ system}

The effects of the different NPs on cell viability were studied using the xCELLigence RTCA DP from Roche (Basel, Switzerland). This system uses plates that contain a gold electrode at the bottom of each well. This electrode can measure the changes in impedance during cell growth in real time, and the method is only suitable for adherent cells.

In this case, NCI $\mathrm{H} 460$ cell line was cultured at $1 \times$ $10^{4}$ cells per well $\left(37^{\circ} \mathrm{C}\right.$ and $\left.5 \% \mathrm{CO}_{2}\right)$ in $200 \mu \mathrm{l}$ of RPMI $10 \% \mathrm{FBS}$ and the sample was incubated for $24 \mathrm{~h}$, after which the exponential phase had been reached. The medium was removed and $200 \mu \mathrm{l}$ of each treatment were added. The NPs were tested at six different concentrations by performing serial dilutions (1:2) starting from $500 \mu \mathrm{g} / \mathrm{ml}$. In the case of $\mathrm{ZnO} \mathrm{Nps}$, the starting dilution was $100 \mu \mathrm{g} / \mathrm{ml}$ in order to calculate an accurate LD50. Culture medium and NPs alone at the highest concentration were used as negative control. The whole experiment lasted $72 \mathrm{~h}$ and the impedance was monitored at 15 -min intervals. The LD50 values were calculated using RTCA Software 1.2.1.

\section{Cell culture \& incubation with the nanoparticles}

Signaling pathway activation assays were performed on the human tumoral NCI-H460 cell line, which was purchased from ATCC (American Type Culture Collection, Manassas, VA, USA). Cells were cultured at $37^{\circ} \mathrm{C}$ in $5 \% \mathrm{CO}_{2}$ with RPMI 1640 medium supplemented with $10 \%$ FBS and Penicillin-Streptomycin (Gibco, Life Technologies, CA, USA). The NCI-H460 lung adenocarcinoma cell line was seeded at a density of $5 \times 10^{6}$ in $25 \mathrm{~cm}^{2}$ culture flasks (Falcon ${ }^{\mathrm{TM}}$ BD Biosciences, NJ, USA). Except for $\mathrm{ZnO}$ (used at 5 and $50 \mu \mathrm{g} /$ $\mathrm{ml}$ due to its high cytotoxicity), Nps were added to the cells at concentrations of 10 and $100 \mu \mathrm{g} / \mathrm{ml}$. The influence that $\mathrm{Zn}^{2+}$ ions had on $\mathrm{ZnO} \mathrm{Np}$-induced cell activation was also studied with a stock of $10 \mathrm{mg} / \mathrm{ml} \mathrm{ZnCl}_{2}$ (Sigma-Aldrich Co. LLC, MO, USA) prepared in milli$\mathrm{Q}$ water. The stock solution was added to the cells to give final $\mathrm{Zn}^{2+}$ concentrations of 1,10 and $100 \mu \mathrm{g} / \mathrm{ml}$.

The cells were incubated with the Nps for different times and they were then washed with phosphatebuffered saline (PBS).

Study of the MAPK \& NFKB activation pathways Cell extracts were prepared in a lysis buffer with $10 \mathrm{mM}$ Tris. $\mathrm{HCl}[\mathrm{pH}$ 8], $150 \mathrm{mM} \mathrm{NaCl}, 2.5 \mathrm{mM}$
EDTA, 1\% NP-40 and a protease and phosphatase inhibitor cocktail (Complete Mini and PhosphoStop from Roche Ltd., Basel, Switzerland). The cell lysates were centrifuged $\left(16,000 \times g\right.$ at $4^{\circ} \mathrm{C}$ for $\left.5 \mathrm{~min}\right)$ in an Eppendorf 5415 R centrifuge (Eppendorf AG, Hamburg, Germany) to remove the cell residue and Nps. Cell extracts were resolved on 10\% SDS-PAGE gels and transferred to polyvinylidene difluoride (PVDF) membranes (Immun-BlotTM $0.2 \mu \mathrm{m}$, BioRad Laboratories, Inc., CA, USA). The membranes were washed with Tris buffer saline with $1 \%$ Tween-20 (TBST) and blocked with 5\% skimmed milk (Sigma-Aldrich Co.) in TBST for $1 \mathrm{~h}$ at room temperature.

The phosphorylation of ERK1/2, p38 and SAPK/ JNK kinases was determined in western blots probed with specific rabbit monoclonal anti-human p-ERK1/2, p-p38 and p-SAPK/JNK antibodies against the phosphorylated proteins diluted 1:10,0001:20,000 in TBST. All antibodies were purchased from Cell Signaling Tech (MA, USA). Anti-GAPDH rabbit polyclonal antibodies were used at 1:80,000 as internal control (Sigma-Aldrich Co. LLC).

NFкB activation was assessed through the degradation of the I $\mathrm{I} B \alpha$ inhibitor in western blots probed with an anti-IkB $\alpha$ monoclonal antibody diluted at $1: 10,000$. Due to overlap with the GAPH protein, the value used to normalize the results for the IкB $\alpha$ protein was the mean intensity of the GAPDH obtained in the other western blots, taking into account the fact that the same volume of protein extract was loaded for each sample.

Goat anti-rabbit HRP-conjugated IgG antibodies diluted 1:50,000 in TBST with $2.5 \%$ skimmed milk were used as secondary antibodies. Antibody binding was detected with the Clarity ${ }^{\mathrm{TM}}$ Western ECL Substrate, and the protein bands were analyzed and quantified using the ChemiDoc XRS imaging system, both from Bio-Rad Laboratories (Hercules, CA, USA). Three independent experiments were performed for each condition and a one-way ANOVA was performed to test the homogeneity of the variances, followed by a Dunnett's T3 or a Tukey's statistical test to compare the treated samples with the control (untreated sample): statistical significance $(\mathrm{p}<0.05)$. In the cases where statistical studies were not carried out, two or three independent experiments were performed.

\section{Cytokine detection in human peripheral blood mononuclear cells}

The release of cytokines was studied in PBMCs from three different healthy donors treated independently. The PBMCs were obtained by density gradient using Ficoll-Paque PLUSTM from GE Healthcare (Uppsala, Sweden). Briefly, EDTA anticoagulated blood was 
diluted with an equal volume of PBS and added to Ficoll in a 7:3 ratio (diluted Blood:Ficoll) and centrifuged at $180 \times g$ for $30 \mathrm{~min}$ at $20^{\circ} \mathrm{C}$. The mononuclear cells, which were located at the interface between Ficoll and plasma, were collected with a Pasteur pipette and washed twice with complete medium by centrifugation at $100 \times g$ for $5 \mathrm{~min}$ at $20^{\circ} \mathrm{C}$.

Then $1 \times 10^{5}$ hPBMCs were incubated in 96-well plates in the presence of the NPs at two different concentrations: 20 and $200 \mu \mathrm{g} / \mathrm{ml}$. As a positive control, cells were incubated with a combination of lipopolysaccharide (LPS) from InvivoGen (CA, USA) and phytohemagglutinin (PHA) from Sigma-Aldrich (MO, USA) at 1 and $10 \mu \mathrm{g} / \mathrm{ml}$, respectively. Culture medium was used as a negative control.

After $24 \mathrm{~h}$ of incubation at $37^{\circ} \mathrm{C}$ with $5 \% \mathrm{CO}_{2}$, the plate was centrifuged $\left(100 \times g, 5 \mathrm{~min}, 4^{\circ} \mathrm{C}\right)$ and the supernatant was collected and stored at $-20^{\circ} \mathrm{C}$ prior to analysis. The concentrations of 11 different cytokines (IFN- $\gamma$, IL-1 $\beta$, IL-2, IL-4, IL-5, IL-6, IL-8, IL-10, IL-12 p70, TNF- $\alpha$, TNF- $\beta$ ) were determined using the FlowCytomix ${ }^{\mathrm{TM}}$ Th1/Th2 kit from eBioscience (CA, USA) according to the manufacturer's instructions. This kit allows the simultaneous detection of different cytokines as it is based on antibodyconjugated beads that can be differentiated by their sizes and by their distinct spectral ranges. Finally, the samples were studied by flow cytometry (FC500, Beckman-Coulter; FL, USA) and data were analyzed with the FlowCytomix Pro 3.0 Software (eBioscience, CA, USA).

The panel of cytokines studied was divided into type 1 cytokines, including those cytokines that induce a Th1 or cellular response, and type 2 cytokines, which are released in a Th2 or humoral response. Other cytokines were also evaluated such as IL-8, a cytokine that induces chemotaxis in target cells, IL-1 $\beta$, an important mediator of inflammatory response, and TNF- $\alpha$, which is involved in systemic inflammation and acute phase reaction.

Institutional ethics approval to work with human samples from healthy donors was obtained from the Ethics Committee for Clinical Research (Xunta de Galicia, Spain. 2014/497). All participants included in the study gave their written informed consent.

\section{Results}

\section{Cell viability}

Cells were incubated with different concentrations of $\mathrm{Nps}\left(\mathrm{TiO}_{2}, \mathrm{CeO}_{2}, \mathrm{Al}_{2} \mathrm{O}_{3}\right.$ and $\left.\mathrm{ZnO}\right)$ and the proliferation curves obtained are shown in Figure 1.

Cell toxicity was not observed at the concentrations tested using $\mathrm{TiO}_{2}, \mathrm{CeO}_{2}$ or $\mathrm{Al}_{2} \mathrm{O}_{3} \mathrm{Nps}$ (Figure 1A) and only a slight reduction in cell proliferation was evident at the highest concentrations, especially for $\mathrm{Al}_{2} \mathrm{O}_{3} \mathrm{Nps}$. However, $\mathrm{ZnO} \mathrm{Nps}$ were very toxic and they induced cell toxicity with a lethal dose 50 (LD50) of $49.93 \mu \mathrm{g} /$ $\mathrm{ml}$. According to our results with $\mathrm{ZnO} \mathrm{Nps}$, there is a concentration range over which the cell viability is dramatically reduced, with nearly $100 \%$ of the cells killed [39]. This finding is consistent with the hypothesis that the release of $\mathrm{Zn}^{2+}$ could be the main cause of cell toxicity.

The toxicity of the $\mathrm{ZnO}$ Nps was also characterized by performing a colorimetric test in the Jurkat cell line (Supplementary Information). The LD50 in Jurkat cells (Supplementary Figure 1) was close to the value found for the NCI-H460 cell line. In a similar way to this cell line, the other Nps did not have any effect on the cell viability (data not shown).

\section{ZnO Nps activate MAPK phosphorylation in $\mathrm{NCl}-\mathrm{H} 460$ cells}

The MAPK phosphorylation (p-ERK1/2, p38 and p-SAPK/JNK) was initially measured in order to determine which pathways were activated in NCIH460 cells by different Nps. When cells were exposed to the Nps for 1 or $3 \mathrm{~h}$, only the $\mathrm{ZnO} \mathrm{Nps}$ at the highest concentration activated the three different MAPKs (Figure 2). The p-ERK1/2 bands were the most intensely labeled after $1 \mathrm{~h}$, whereas the p-p38 and p-SAPK/JNK levels were stronger after $3 \mathrm{~h}$ in the presence of these Nps. By contrast, none of the other metal oxide $\mathrm{Nps}$ tested $\left(\mathrm{CeO}_{2}, \mathrm{TiO}_{2}\right.$ and $\left.\mathrm{Al}_{2} \mathrm{O}_{3}\right)$ activated any MAPK (Figure 2). Longer times in the presence of the $\mathrm{CeO}_{2}$ and $\mathrm{TiO}_{2} \mathrm{Nps}(6 \mathrm{~h})$ also failed to produce any positive effect. Likewise, exposure of NCI-H460 cells to a tenfold lower concentration of each $\mathrm{Np}$ did not activate any MAPK (Figure 3).

\section{$\mathrm{ZnO} \& \mathrm{Al}_{2} \mathrm{O}_{3}$ Nps activate the NF $\kappa$ B pathway}

Activation of the NFKB pathway is characterized by degradation of the I $\mathrm{K} \mathrm{B} \alpha$ inhibitor. However, this degradation was not observed in the NCI-H460 cells incubated with the $\mathrm{CeO}_{2}$ and $\mathrm{TiO}_{2} \mathrm{Nps}(100 \mu \mathrm{g} / \mathrm{ml}$ : Figure 2), except for the slight degradation evident in cells maintained for $6 \mathrm{~h}$ in the presence of $\mathrm{TiO}_{2} \mathrm{Nps}$. By contrast, $\mathrm{ZnO}(50 \mu \mathrm{g} / \mathrm{ml})$ and $\mathrm{Al}_{2} \mathrm{O}_{3}(100 \mu \mathrm{g} / \mathrm{ml})$ Nps both altered the amount of $I \kappa B \alpha$ protein in this lung tumor cell line (Figure 2). These Nps increased I $\kappa \mathrm{B} \alpha$ protein expression compared with the controls, but this protein almost completely disappeared from cells maintained for $3 \mathrm{~h}$ with the $\mathrm{ZnO}$ Nps. Conversely, in the presence of $\mathrm{Al}_{2} \mathrm{O}_{3} \mathrm{Nps}$ the amount of this protein remained higher than in the control cells. At a concentration ten-times lower, only $\mathrm{ZnO} \mathrm{Nps}$ induced some degradation of the I $\mathrm{I} B \alpha$ protein at both times (Figure 3). 

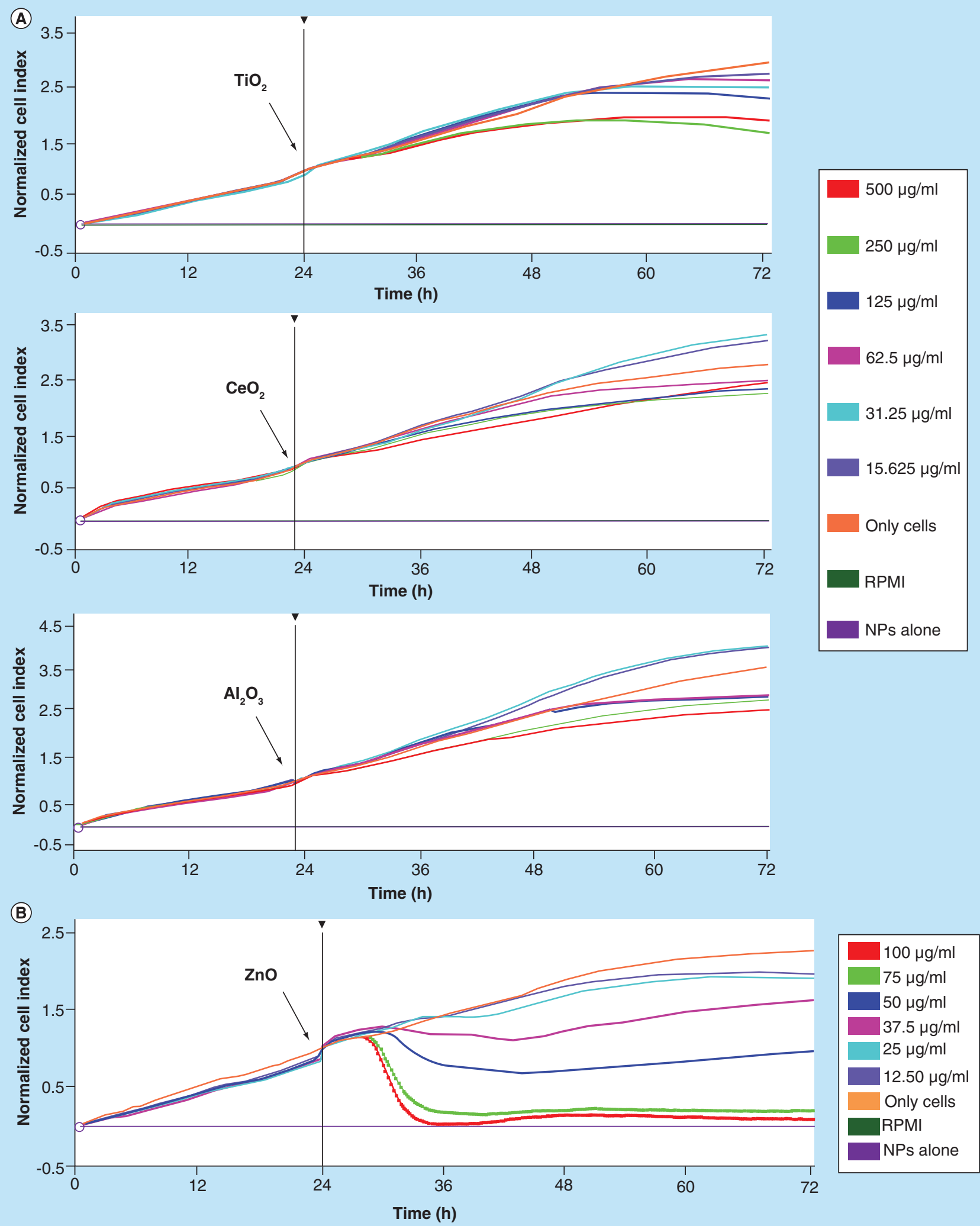

Figure 1. Effect of $\mathrm{Nps}$ on the viability of $\mathrm{NCI} \mathbf{H 4 6 0}$ cells.Cells were allowed to grow until they reached the exponential phase.

(A) $\mathrm{TiO}_{2}, \mathrm{CeO}_{2}$ and $\mathrm{Al}_{2} \mathrm{O}_{3} \mathrm{NPs}$ were added (indicated with an arrow) at different concentrations: 15.6 (violet line), 31.25 (blue line), 62.5 (pink line), 125 (dark blue line), 250 (green line) and $500 \mu \mathrm{g} / \mathrm{ml}$ (red line). (B) ZnO Nps were added (indicated with an arrow) at different concentrations: 12.5 (violet line), 25 (blue line), 37.5 (pink line), 50 (dark blue line), 75 (green line) and $100 \mu \mathrm{g} / \mathrm{ml}$ (red line). The calculated LD50 was around $50 \mu \mathrm{g} / \mathrm{ml}$. 


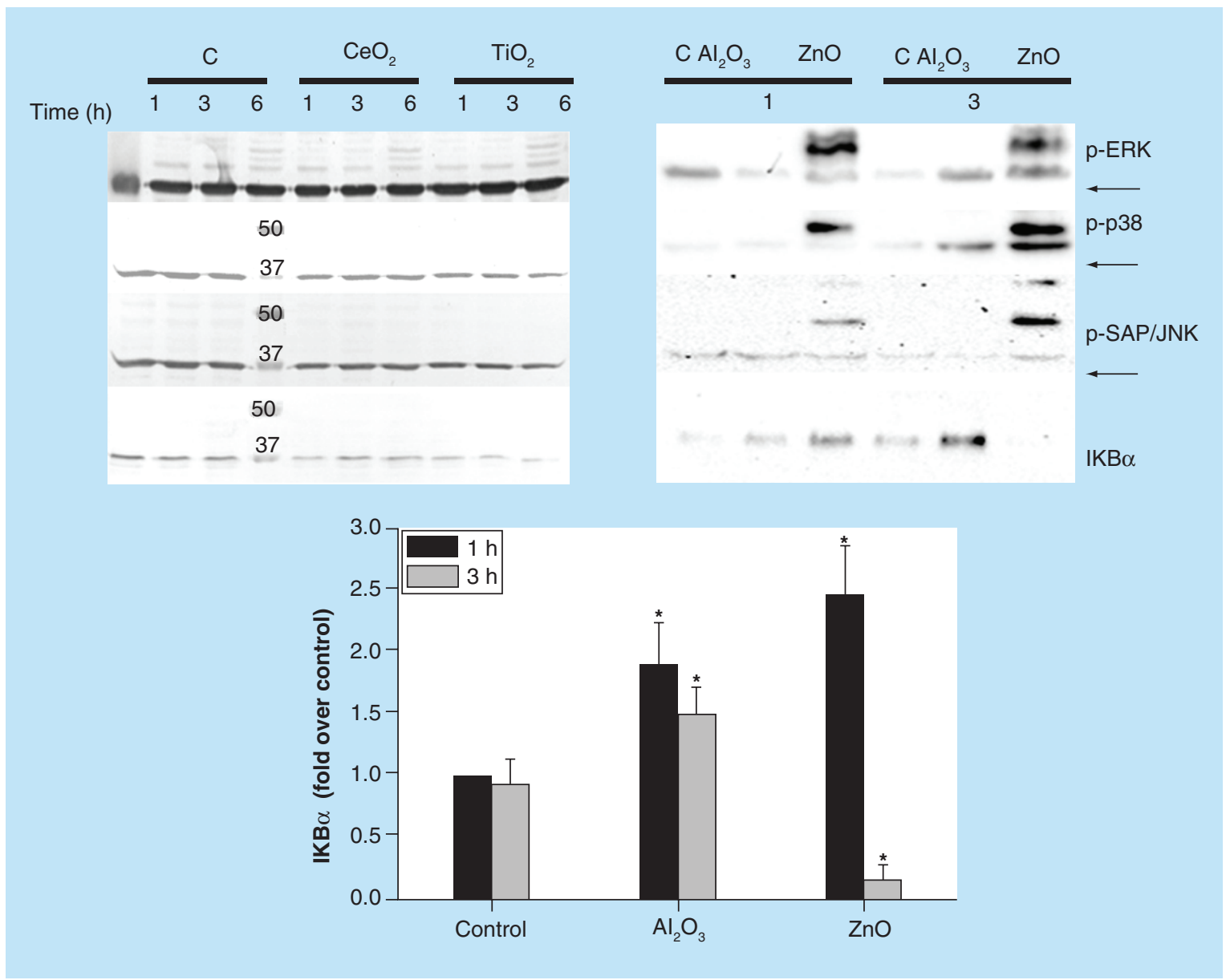

Figure 2. Activation of the MAPK (p-ERK1/2, p38 and p-SAPK/JNK) and the NFKB pathways induced by $\mathrm{CeO}_{2}, \mathrm{TiO}_{2}$, $\mathrm{Al}_{2} \mathrm{O}_{3}$ and $\mathrm{ZnO} \mathrm{Nps}$ in the $\mathrm{NCl}-\mathrm{H} 460$ lung cell line. The activation of the MAPK and NFKB pathways was studied by western blot. The expression of phosphorylated ( $p$ ) proteins ( $p$-ERK1/2, $p-38$ and $p$-SAP/JNK) is indicated at different time points $(1,3$ and $6 \mathrm{~h}$ ). All Nps were tested at $100 \mu \mathrm{g} / \mathrm{ml}$, except for $\mathrm{ZnO}(50 \mu \mathrm{g} / \mathrm{ml})$. The numbers in the figure correspond to the molecular weight of the protein marker and GAPDH was used as a loading control

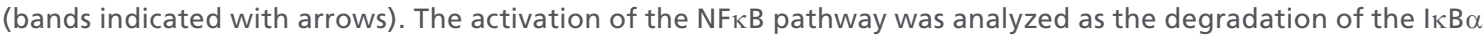
inhibitor by western blot and normalized to the controls ( $C$, untreated sample) at different times (1, $3 \mathrm{~h}$ ).

*Statistically significant differences $(p<0.05)$ in the protein level compared with the control.

Effect of $\mathrm{Zn}^{2+}$ ions on the activation pathways induced by ZnO Nps

In order to assess whether the effect induced by $\mathrm{ZnO}$ Nps on NCI-H460 cells was due to the Np itself or to the action of $\mathrm{Zn}^{2+}$ ions alone, the cells were exposed to $\mathrm{ZnCl}_{2}$ (1, 10 and $100 \mu \mathrm{g} / \mathrm{ml} \mathrm{Zn}^{2+}$ ions) and MAPK and NFKB activation was subsequently assessed in western blots (Figure 4).

Phosphorylation of proteins involved in the activation pathways was observed in the presence of the highest dose of $\mathrm{ZnCl}_{2}$ (Figure 4). The phosphorylation of p38 and SAP/JNK proteins was clearly detected after $3 \mathrm{~h}$ in the presence of the highest concentration of $\mathrm{ZnCl}_{2}$. In the case of $\mathrm{p} 38$ some subtle activation was also observed with $10 \mu \mathrm{g} / \mathrm{ml}$ of the zinc salt.

Activation of ERK1/2 was detected in NCI-H460 cells at both time points ( 1 and $3 \mathrm{~h})$ and this finding is consistent with the results previously found for $\mathrm{ZnO}$ Nps (Figure 2). Interestingly, the degradation of I $\mathrm{K} B \alpha$, the inhibitor of the NFKB protein, was also detected in cells exposed to a low salt concentration $(1 \mu \mathrm{g} /$ $\mathrm{ml}$ ) and the level of degradation increased with both concentration and time of exposure (Figure 4).

\section{$\mathrm{ZnO} \& \mathrm{Al}_{2} \mathrm{O}_{3} \mathrm{Nps}$ induce secretion of cytokines}

In an effort to determine the potential inflammatory and immunogenic properties induced by the metal oxide Nps, a multiplex analysis of 11 cytokines was carried out in human PBMCs. This analysis showed that $\mathrm{ZnO}$ and $\mathrm{Al}_{2} \mathrm{O}_{3}$ Nps were the only Nps that induced the release of IL-8 in human PBMCs, and $\mathrm{ZnO} \mathrm{Nps}$ induced the release of other inflammatory cytokines such as IL-1 $\beta$, IL- 6 and TNF- $\alpha$ (Table 1 \& Supplementary Table 1). The $\mathrm{CeO}_{2}$ and $\mathrm{TiO}_{2}$ 


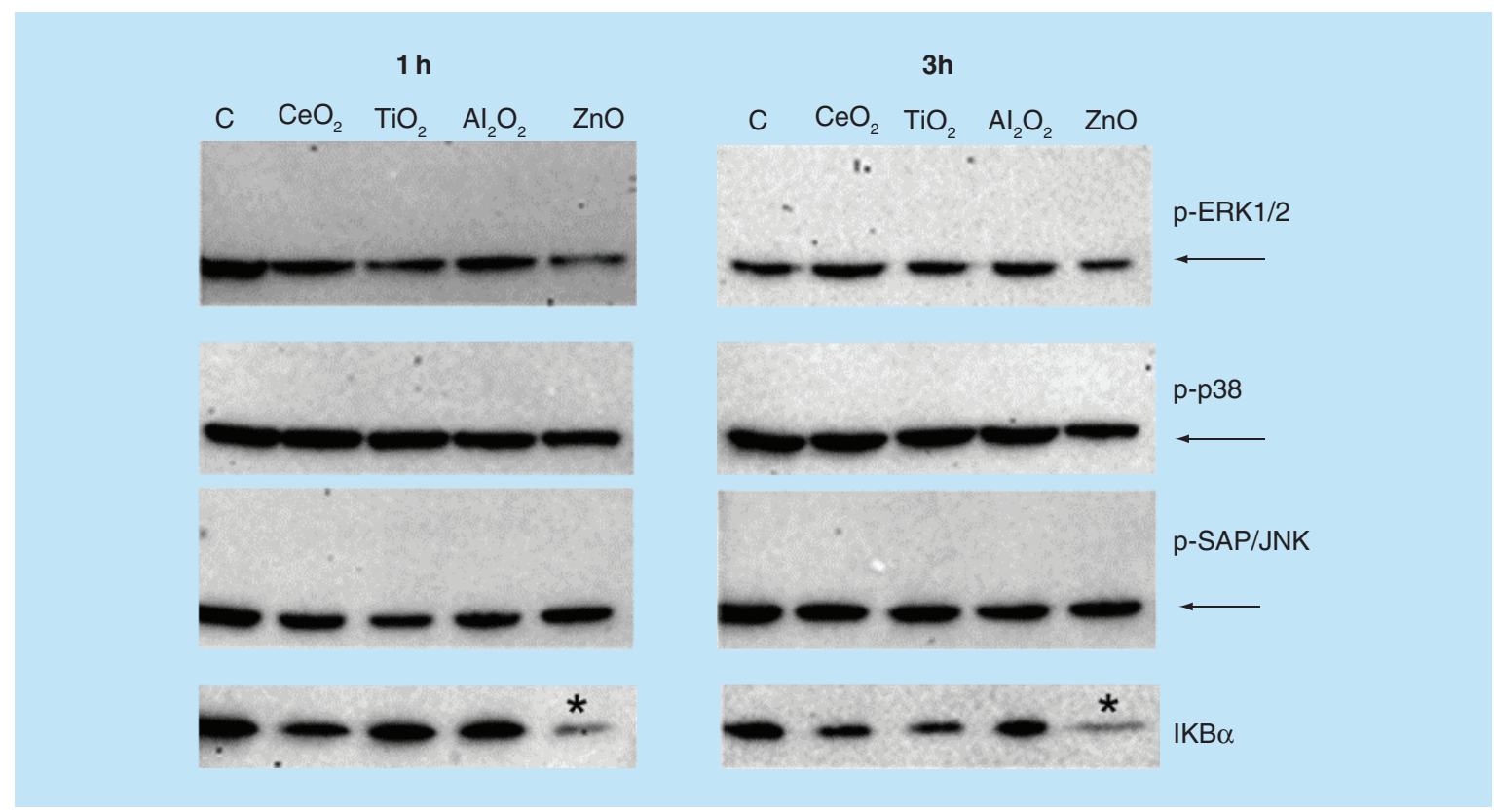

Figure 3. Expression of the MAPK and IKB $\alpha$ protein in $\mathrm{NCl}-\mathrm{H} 460$ cells incubated with low concentrations of $\mathrm{CeO}_{2}$, $\mathrm{TiO}_{2}, \mathrm{Al}_{2} \mathrm{O}_{3}$ and $\mathrm{ZnO}$ Nps. The activation of the MAPK and NFKB pathways was studied by western blot at two different time points ( 1 and $3 \mathrm{~h}$ ). All Nps were tested at $10 \mu \mathrm{g} / \mathrm{ml}$, except for $\mathrm{ZnO} \mathrm{Nps}(5 \mu \mathrm{g} / \mathrm{ml})$. The expected bands corresponding to the phosphorylated p-ERK1/2, p-38 and p-SAP/JNK are indicated, but they were not detected in the $\mathrm{NCl}-\mathrm{H} 460$ cell line at these $\mathrm{Np}$ concentrations. GAPDH was used as a loading control and the bands are indicated with arrows. The activation of the NFKB pathway was analyzed by the degradation of the $I \kappa B \alpha$ inhibitor.

*Statistically significant differences $(p<0.05)$ in the protein level compared with the control.

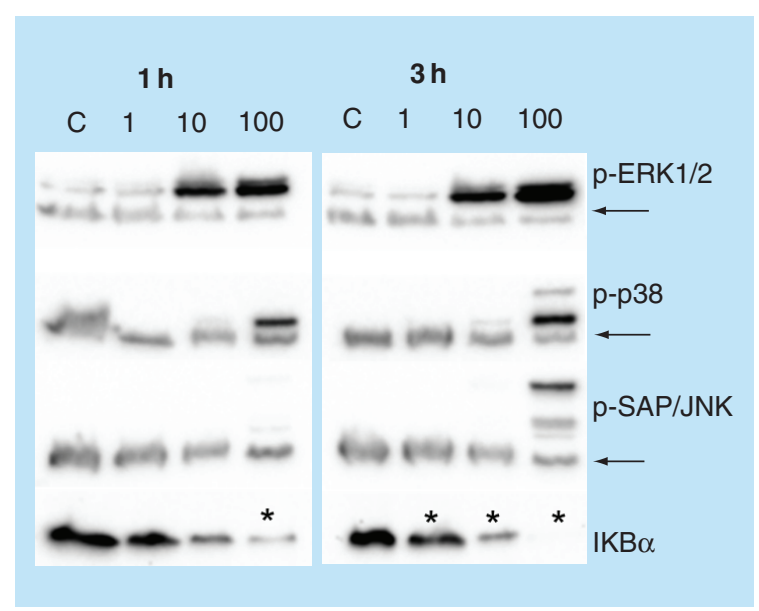

Figure 4. Influence of the $\mathrm{Zn}^{2+}$ ion concentration on the activation of the MAPK and NFKB pathways in $\mathrm{NCl}-\mathrm{H} 460$ cells.The activation of the MAPK and NFKB pathways in $\mathrm{NCl}-\mathrm{H} 460$ cells was studied by western blot at two different time points ( 1 and $3 \mathrm{~h}$ ) and at three different concentrations $(1,10$ and $100 \mu \mathrm{g} / \mathrm{ml})$ of $\mathrm{Zn}^{2+}$ ions. The expression of phosphorylated $(p)$ proteins ( $p$-ERK1/2, p-38 and p-SAP/JNK) is indicated along with the degradation of the IKB $\alpha$ inhibitor. GAPDH was used as a loading control and the bands are indicated with arrows.

Statistically significant differences $(p<0.05)$ in the protein level compared with the control.
Nps induced some cytokine secretion, but only in one or two out of three samples.

\section{Discussion}

The effects induced at the cellular and molecular levels by four common metal oxide $\mathrm{Nps}\left(\mathrm{CeO}_{2}, \mathrm{TiO}_{2}, \mathrm{Al}_{2} \mathrm{O}_{3}\right.$ and $\mathrm{ZnO}$ ) on a lung epithelial cell line were characterized by measuring the cell proliferation and the activation of MAPK and NFKB pathways.

$\mathrm{ZnO}$ Nps were the most toxic to the epithelial lung cells (Figure 1) of all the Nps studied and they induced the activation of the three main MAPKs (ERK1/2, p38, SAP/JNK) and the NFKB pathways (Figure 2). Nevertheless, this activation was not detected at the lowest concentration tested, $5 \mu \mathrm{g} / \mathrm{ml}$, except for the $\mathrm{NF} \kappa \mathrm{B}$ transcription factor (Figure 3 ).

The activation of the mainly apoptotic SAP/JNK pathway at the highest concentration is consistent with the cytotoxicity observed for these Nps (Figure 1), which showed an LD50 of approximately $50 \mu \mathrm{g} / \mathrm{ml}$ in the NCI-H460 cell line. A similar cytotoxicity pattern was described for these Nps in different cell lines [33] including Jurkat cells (Supplementary Figure 1).

$\mathrm{CeO}_{2} \mathrm{Nps}$ were the most innocuous of the four metal oxide Nps studied for the lung cells as they failed to induce activation of any of the signaling pathways 
Table 1. Cytokine release after incubation of human peripheral blood mononuclear cells with the different metal oxide Nps at two different concentrations: 20 and $200 \mu \mathrm{g} / \mathrm{ml}$.

\begin{tabular}{|c|c|c|c|c|c|c|}
\hline & & $\mu \mathrm{g} / \mathrm{ml}$ & $\mathrm{ZnO}$ & $\mathrm{TiO}_{2}$ & $\mathrm{CeO}_{2}$ & $\mathrm{Al}_{2} \mathrm{O}_{3}$ \\
\hline \multirow[t]{8}{*}{ Th1 profile } & \multirow[t]{2}{*}{ IL 2} & 20 & - & - & $+1 / 3$ & - \\
\hline & & 200 & - & $+1 / 3$ & - & $+1 / 3$ \\
\hline & \multirow[t]{2}{*}{ IFN- $\gamma$} & 20 & - & $+1 / 3$ & $+1 / 3$ & - \\
\hline & & 200 & - & - & - & - \\
\hline & \multirow[t]{2}{*}{ IL-12p70 } & 20 & - & - & - & - \\
\hline & & 200 & - & - & - & - \\
\hline & \multirow[t]{2}{*}{ TNF- $\beta$} & 20 & - & - & - & - \\
\hline & & 200 & - & - & - & - \\
\hline \multirow[t]{8}{*}{ Th2 profile } & \multirow[t]{2}{*}{ IL4 } & 20 & - & - & - & - \\
\hline & & 200 & - & - & - & - \\
\hline & \multirow[t]{2}{*}{ IL5 } & 20 & - & - & - & - \\
\hline & & 200 & - & - & - & - \\
\hline & \multirow[t]{2}{*}{ IL6 } & 20 & + & - & - & - \\
\hline & & 200 & + & - & - & $+1 / 3$ \\
\hline & \multirow[t]{2}{*}{ IL10 } & 20 & - & $+1 / 3$ & - & - \\
\hline & & 200 & - & $+1 / 3$ & $+1 / 3$ & $+1 / 3$ \\
\hline \multirow{6}{*}{$\begin{array}{l}\text { Other pro-inflammatory } \\
\text { cytokines }\end{array}$} & \multirow[t]{2}{*}{ IL8 } & 20 & ++ & - & - & + \\
\hline & & 200 & ++ & - & - & + \\
\hline & \multirow[t]{2}{*}{ IL1 $\beta$} & 20 & + & $+1 / 3$ & $+2 / 3$ & - \\
\hline & & 200 & + & $+1 / 3$ & $+1 / 3$ & $+2 / 3$ \\
\hline & \multirow[t]{2}{*}{ TNF- $\alpha$} & 20 & + & - & $+1 / 3$ & - \\
\hline & & 200 & + & $+1 / 3$ & $+1 / 3$ & $+1 / 3$ \\
\hline
\end{tabular}

at 10 and $100 \mu \mathrm{g} / \mathrm{ml}$ (Figures 2 and 3). $\mathrm{TiO}_{2} \mathrm{Nps}$ were also unable to induce any of the signaling pathways, except for a slight degradation of the NFKB inhibitor, the I $\mathrm{B} \alpha$ protein, at $6 \mathrm{~h}$ (Figure 2).

$\mathrm{Al}_{2} \mathrm{O}_{3}$ Nps increased the expression of the IкB $\alpha$ protein at the highest concentration tested, but not at a concentration that was ten-times lower (Figure 3). This effect could be due to activation of the NFkB pathway as the inhibitor $I \kappa \mathrm{B} \alpha$ protein is activated by the nuclear factor in an inhibitory feedback loop [40].

The influence of ion release on the activation routes was also tested for $\mathrm{ZnO} \mathrm{Nps}$ by using $\mathrm{ZnCl}_{2}$. Activation of SAP/JNK was only detected at the highest concentration $\left(100 \mu \mathrm{g} / \mathrm{ml} \mathrm{Zn}^{2+}\right)$ and after $3 \mathrm{~h}$ of incubation (Figure 4), whereas activation of the protein by the $\mathrm{ZnO}$ Nps was already detected at a lower concentration $(50 \mu \mathrm{g} / \mathrm{ml})$ and in a shorter time (1 h) (Figure 2). The p38 and ERK1/2 proteins were activated at both 10 and $100 \mu \mathrm{g} / \mathrm{ml} \mathrm{Zn}^{2+}$ although the phosphorylation of p38 was very low at the lower concentration.
Degradation of the I $\mathrm{B} \mathrm{B} \alpha$ protein was detected at all ion concentrations tested in a similar way to the findings for the $\mathrm{ZnO}$ Nps. Hence, $\mathrm{Zn}^{2+}$ ions were able to reproduce the cell activation induced by the $\mathrm{ZnO}$ Nps. Although there might by other cellular effects due to the Nps themselves, it is probable that the main toxicity mechanism for these $\mathrm{Nps}$ is due to the $\mathrm{Zn}^{2+}$ ions, as determined previously for other cell lines [34-36]. In addition to their dissolution in the medium, Nps can be further solubilized in the cell lysosomes and this would increase the ion concentration within the cells [36].

$\mathrm{ZnO}$ Nps were also able to induce the NFкB pathway at both concentrations tested, thus indicating an inflammatory potential on the lung cells. This activation has also been observed in human bronchial epithelial cells [32]. In fact, ultrafine $\mathrm{ZnO}$ particles are capable of reaching the alveoli and they can induce metal-fume fever [41]. Although the use of an epithelial lung cell line is not the optimal model, we selected this type of cell rather than primary cells. The difficulty in 
obtaining primary human airway epithelial cells and the interindividual variability due to prior activation with other stimuli such as smoking would complicate the characterization.

Activation of the $\mathrm{NF \kappa B}$ pathway by the $\mathrm{Al}_{2} \mathrm{O}_{3}$ $\mathrm{Nps}$ at the highest concentration tested could also be related to an inflammatory event. For example, $\mathrm{Al}_{2} \mathrm{O}_{3}$ dust has been linked to pulmonary fibrosis in workers exposed to these particulates, and aluminium constituted more than $90 \%$ of the metals detected in their lungs [42]. Our results indicate that activation of the different pathways is dose-dependent and such activation was not detected at low concentrations.

In agreement with the activation of the NFKB pathway in the lung cell line, which is mainly linked to inflammation, it was found that $\mathrm{ZnO}$ and $\mathrm{Al}_{2} \mathrm{O}_{3} \mathrm{Nps}$ were the only Nps that were able to induce IL- 8 release in human PBMCs (Table 1 \& Supplementary Table 1). In the case of the $\mathrm{ZnO} \mathrm{Nps}$, other inflammatory cytokines, such as IL-6, IL-1 $\beta$ and TNF- $\alpha$, were also produced by these cells. Hence, these Nps have proinflammatory properties and are potentially harmful not only for the lung, but also for other tissues and cells. The interaction of the metal oxide Nps with immune cells was studied in a previous work in which human peripheral blood leukocytes from healthy donors were used [43]. The results showed a decrease in the chemotactic response of the leukocytes to SDF-1 $\alpha$ in the presence of $\mathrm{ZnO} \mathrm{Nps}$, and an increase in the cell proliferation induced by phytohemagglutinin (PHA) in the presence of $\mathrm{Al}_{2} \mathrm{O}_{3}$ and $\mathrm{TiO}_{2} \mathrm{Nps}$.

In contrast to $\mathrm{ZnO}$ and $\mathrm{Al}_{2} \mathrm{O}_{3}, \mathrm{CeO}_{2}$ and $\mathrm{TiO}_{2}$ Nps did not show any harmful effects toward the lung epithelial cells and only $\mathrm{TiO}_{2}$, at the highest concentration and longest incubation time tested, seemed to induce some degradation of $\mathrm{I} \kappa \mathrm{B} \alpha$, the NFкB inhibitor. Nevertheless, $\mathrm{TiO}_{2}$ and $\mathrm{CeO}_{2} \mathrm{Nps}$ produced some cytokines for only one or two in three samples from healthy volunteers. Hence, although these Nps are apparently safe for epithelial lung cells, they potentially could have inflammatory or allergenic properties for some individuals.

\section{Conclusion}

A comparative study of human lung epithelial cell activation by four different metal oxides $\left(\mathrm{CeO}_{2}\right.$, $\mathrm{TiO}_{2}, \mathrm{Al}_{2} \mathrm{O}_{3}$ and $\mathrm{ZnO}$ ), using the NCI-H460 cell line, showed that only $\mathrm{ZnO}$ Nps were able to induce activation of the ERK, p38 and SAP/JNK kinases, as characterized by detection of the phosphorylated protein using western blot. Activation of the mainly apoptotic SAP/JNK kinases is consistent with the cytotoxic potential of these Nps. Moreover, cells in the presence of $\mathrm{ZnCl}_{2}$ - as a source of $\mathrm{Zn}^{2+}$ ions - gave a similar activation pattern as the cells incubated with $\mathrm{ZnO}$ $\mathrm{NPs}$, which suggests that the ions released by the $\mathrm{ZnO}$ Nps are mainly responsible for the effects observed on the cells. Both $\mathrm{ZnO}$ and $\mathrm{Al}_{2} \mathrm{O}_{3} \mathrm{Nps}$ activated mainly inflammatory NFKB pathway (studying the degradation of the I $\kappa \mathrm{B} \alpha$ inhibitor). This pro-inflammatory character was further confirmed by the cytokine profile obtained in human PBMCs incubated with these Nps. Finally, $\mathrm{CeO}_{2}$ and $\mathrm{TiO}_{2} \mathrm{Nps}$ showed a much safer profile, with only minor effects observed on the aforementioned cells.

\section{Future perspective}

The results of the study described here demonstrate that Nps can activate different cell signaling pathways. Analysis of the possible activation of these routes is also important to understand the effect that the Nps have on the cells besides toxicity, ROS generation or genotoxicity.

The characterization of the cell activation at the molecular level will allow a better understanding of the mechanism by which Nps can exert harmful effects. Each type of $\mathrm{Np}$ would require an independent study because any subtle variation could induce a marked difference in how the Nps interact with the cells, but over a long period these studies could provide relevant information on the potential effects in vivo. In fact, one of the main problems currently faced in the field of nanotoxicology is the lack of standardized in vitro methods to study the increased variety of $\mathrm{Nps}$ that are already being produced, and the poor correlation between the effects observed in vitro and in vivo. The characterization of the activation at the molecular level could contribute to the identification of parameters related with physiological or pathological processes. The activation of signaling proteins could be one of these key parameters that should be characterized in different cell types to predict the potential harmful or beneficial effects of any type of Np. The development of new and faster techniques to measure the activation of a large number of signaling proteins in a single experiment would allow these types of assays to be included in routine nanotoxicology studies.

\section{Supplementary data}

To view the supplementary data that accompany this paper please visit the journal website at: http://www.future-science. com/doi/full/10.4155/FSO.16.2

\section{Financial \& competing interests disclosure}

This work was supported by the HINAMOX project (228825, FP7-NMP-SMALL-2) and the Xunta de Galicia (INBIOMED 2012/273, DXPCTSUG-FEDER, Grupo de Potencial de Crecimiento GPC2013-005). We also thank the BIOCAPS project (316265, FP7/REGPOT-2012-2013.1) and T Lozano-Fernández 
acknowledges an FPU fellowship (Spanish Ministry of Education). The authors have no other relevant affiliations or financial involvement with any organization or entity with a financial interest in or financial conflict with the subject matter or materials discussed in the manuscript apart from those disclosed.

No writing assistance was utilized in the production of this manuscript.

\section{Ethical conduct of research}

The authors state that they have obtained appropriate institutional review board approval or have followed the principles outlined in the Declaration of Helsinki for all human or animal experimental investigations. In addition, for investigations involving human subjects, informed consent has been obtained from the participants involved.

\section{Open access}

This article is distributed under the terms of the Creative Commons Attribution License 4.0 which permits any use, distribution, and reproduction in any medium, provided the original author(s) and the source are credited. To view a copy of the license, visit http://creativecommons.org/licenses/by/4.0/

\section{Executive summary}

- Metal oxide Nps are widely used in several industrial processes and products such as catalysts, cosmetics, coatings and also in the biomedical field.

- Nps can reach the lung by intentional administration or by accidental exposure and their toxic effects have not been fully characterized.

- At a cellular level, Nps can stimulate the activation of different signaling pathways related with proliferation, inflammation and apoptosis.

- The potential activation of human lung epithelial cells by four different metal oxide Nps was studied in the $\mathrm{NCl}-\mathrm{H} 460$ cell line, and the activation of the three main MAPKs and NFKB was characterized by western blot.

- Cell viability was also studied using a method based on the changes in cell impedance. Only ZnO Nps reduced the viability of the cells and this finding is consistent with other studies that have shown the cytotoxicity of ZnO Nps in different cell types.

- ZnO Nps were able to activate the three MAPKs studied (ERK, p38 and SAP/JNK), and the release of Zn ${ }^{2+}$ ions seems to be the main cause of this effect. These results are consistent with their potential cytotoxicity.

- $\mathrm{ZnO}$ and $\mathrm{Al}_{2} \mathrm{O}_{3} \mathrm{Nps}$ showed inflammatory properties due to activation of the $\mathrm{NF} \kappa \mathrm{B}$ pathway in lung epithelial cells and the release of pro-inflammatory cytokines in human PBMCs.

- $\mathrm{TiO}_{2}$ and $\mathrm{CeO}_{2}$ exhibited safer profiles in the lung cells, with only minor effects observed after treatment with this type of Nps. Nevertheless, the capacity of $\mathrm{TiO}_{2} \mathrm{Nps}$ to increase the proliferation of activated T lymphocytes was shown in a previous work.

\section{References}

Papers of special note have been highlighted as: • of interest;

• of considerable interest

1 Card JW, Zeldin DC, Bonner JC, Nestmann ER. Pulmonary applications and toxicity of engineered nanoparticles. Am. J. Physiol. Lung Cell Mol. Physiol. 295(3), L400-L411 (2008).

2 Maynard AD, Aitken RJ. Assessing exposure to airborne nanomaterials: current abilities and future requirements. Nanotoxicology 1(1), 26-41 (2007).

3 Stern ST, Mcneil SE. Nanotechnology safety concerns revisited. Toxicol. Sci. 101(1), 4-21 (2008).

-. Interesting review about the exposure to nanoparticles and their potencial toxicity.

4 Bermudez E, Mangum JB, Wong BA et al. Pulmonary responses of mice, rats, and hamsters to subchronic inhalation of ultrafine titanium dioxide particles. Toxicol. Sci. 77(2), 347-357 (2004).

5 Warheit DB, Hoke RA, Finlay C, Donner EM, Reed KL, Sayes CM. Development of a base set of toxicity tests using ultrafine $\mathrm{TiO}_{2}$ particles as a component of nanoparticle risk management. Toxicol. Lett. 171(3), 99-110 (2007).

6 Grassian VH, O'shaughnessy, Adamcakova-Dodd A, Pettibone JM, Thorne PS. Inhalation exposure study of titanium dioxide nanoparticles with a primary particle size of 2 to $5 \mathrm{~nm}$. Environ. Health Perspect. 115(3), 397-402 (2007).

7 Warheit DB. Nanoparticles: health impacts? Mater. Today 7(2), 32-35 (2004).

8 Song $\mathrm{Y}, \mathrm{Li}$ X, Du X. Exposure to nanoparticles is related to pleural effusion, pulmonary fibrosis and granuloma. Eur. Respir. J. 34(3), 559-567 (2009).

- Real case of human exposure to nanoparticles.

9 Li JJE, Muralikrishnan S, Ng C-T, Yung L-YL, Bay B-H. Nanoparticle-induced pulmonary toxicity. Exp. Biol. Med. (Maywood) 235(9), 1025-1033 (2010).

10 Fujii T, Hayashi S, Hogg JC, Vincent R, Van Eeden SF. Particulate matter induces cytokine expression in human bronchial epithelial cells. Am. J. Respir. Cell. Mol. Biol. 25(3), 265-271 (2001).

11 Park E-J, Yoon J, Choi K, Yi J, Park K. Induction of chronic inflammation in mice treated with titanium dioxide nanoparticles by intratracheal instillation. Toxicology 260(1-3), 37-46 (2009).

12 Mossman BT, Borm PJ, Castranova V, Costa DL, Donaldson K, Kleeberger SR. Mechanisms of action of inhaled fibers, particles and nanoparticles in lung and cardiovascular diseases. Part. Fibre Toxicol. 4(4), 8974-8977 (2007). 
13 Mroz RM, Schins RPF, Li H et al. Nanoparticle-driven DNA damage mimics irradiation-related carcinogenesis pathways. Eur. Respir. J. 31(2), 241-251 (2008).

14 Bakand S, Hayes A, Dechsakulthorn F. Nanoparticles: a review of particle toxicology following inhalation exposure. Inhalation Toxicol. 24(2), 125-135 (2012).

-• Interesting review about the potential mechanisms of nanotoxicity after inhalation exposure.

15 Veranth JM, Kaser EG, Veranth MM, Koch M, Yost GS. Cytokine responses of human lung cells (BEAS-2B) treated with micron-sized and nanoparticles of metal oxides compared with soil dusts. Part. Fibre Toxicol. 4 2-2 (2007).

16 Sydlik U, Bierhals K, Soufi M, Abel J, Schins RPF, Unfried K. Ultrafine carbon particles induce apoptosis and proliferation in rat lung epithelial cells via specific signaling pathways both using EGF-R. Am. J. Physiol. Lung Cell Mol. Physiol. 291(4), L725-L733 (2006).

17 Mossman BT, Lounsbury KM, Reddy SP. Oxidants and signaling by mitogen-activated protein kinasis in lung epithelium. Am. J. Respir. Cell Mol. Biol. 34(6), 666-669 (2006).

18 Unfried K, Albrecht C, Klotz LO, Von Mikecz A, GretherBeck S, Schins RPF. Cellular responses to nanoparticles: target structures and mechanisms. Nanotoxicology 1(1), 52-71 (2007).

19 Abdelmohsen K, Gerber PA, Von Montfort C, Sies $\mathrm{H}$, Klotz L-O. Epidermal growth factor receptor is a common mediator of quinone-induced signaling leading to phosphorylation of connexin-43: role of glutathione and tyrosine phosphatases. J. Biol. Chem. 278(40), 38360-38367 (2003).

20 Rayet B, Gélinas C. Aberrant rel/nfkb genes and activity in human cancer. Oncogene 18(49), 6938-6947 (1999).

21 Wright J, Christman J. The role of nuclear factor kappa B in the pathogenesis of pulmonary diseases: implications for therapy. Am. J. Respir. Med. 2(3), 211-219 (2003).

22 Schwartz MD, Moore EE, Moore FA et al. Nuclear factorkappa $B$ is activated in alveolar macrophages from patients with acute respiratory distress syndrome. Crit. Care Med. 24(8), 1285-1292 (1996).

23 Edwards MR, Bartlett NW, Clarke D, Birrell M, Belvisi M, Johnston SL. Targeting the NF-kappaB pathway in asthma and chronic obstructive pulmonary disease. Pharmacol. Therapeut. 121(1), 1-13 (2009).

24 Meyer K, Rajanahalli P, Ahamed M, Rowe JJ, Hong Y. $\mathrm{ZnO}$ nanoparticles induce apoptosis in human dermal fibroblasts via p53 and p38 pathways. Toxicol. In Vitro 25(8), 1721-1726 (2011).

25 Cheng G, Guo W, Han L et al. Cerium oxide nanoparticles induce cytotoxicity in human hepatoma SMMC-7721 cells via oxidative stress and the activation of MAPK signaling pathways. Toxicol. In Vitro 27(3), 1082-1088 (2013).

26 Liu X, Sun J. Endothelial cells dysfunction induced by silica nanoparticles through oxidative stress via JNK/P53 and NF-kappaB pathways. Biomaterials 31(32), 8198-8209 (2010).
27 Goncalves D, Chiasson S, Girard D. Activation of human neutrophils by titanium dioxide $\left(\mathrm{TiO}_{2}\right)$ nanoparticles. Toxicol. In Vitro 24(3), 1002-1008 (2010).

28 Park E-J, Yi J, Chung K-H, Ryu D-Y, Choi J, Park K. Oxidative stress and apoptosis induced by titanium dioxide nanoparticles in cultured BEAS-2B cells. Toxicol. Lett. 180(3), 222-229 (2008).

29 Krüger K, Cossais F, Neve H, Klempt M. Titanium dioxide nanoparticles activate IL8-related inflammatory pathways in human colonic epithelial Caco-2 cells. J. Nanopart. Res. 16(5), 1-12 (2014).

30 Matsuda A, Suzuki Y, Honda G et al. Large-scale identification and characterization of human genes that activate NF-kappaB and MAPK signaling pathways. Oncogene 22(21), 3307-3318 (2003).

31 Kim Y-M, Reed W, Lenz AG et al. Ultrafine carbon particles induce interleukin- 8 gene transcription and $\mathrm{p} 38$ MAPK activation in normal human bronchial epithelial cells. Am. J. Physiol. Lung Cell Mol. Physiol. 288(3), L432-L441 (2005).

32 Wu W, Samet JM, Peden DB, Bromberg PA. Phosphorylation of p65 is required for zinc oxide nanoparticle-induced interleukin 8 expression in human bronchial epithelial cells. Environ. Health Perspect. 118(7), 982-987 (2010).

33 Lozano T, Rey M, Rojas E et al. Cytotoxicity effects of metal oxide nanoparticles in human tumor cell lines. J. Phys. Conf. Ser. 304(1), 012046 (2011).

34 Buerki-Thurnherr T, Xiao LS, Diener L et al. In vitro mechanistic study towards a better understanding of $\mathrm{ZnO}$ nanoparticle toxicity. Nanotoxicology 7(4), 402-416 (2013).

- $\quad$ Proposed mechanism of toxicity induced by $\mathrm{ZnO}$ nanoparticles.

35 Tuomela S, Autio R, Buerki-Thurnherr T et al. Gene expression profiling of immune-competent human cells exposed to engineered zinc oxide or titanium dioxide nanoparticles. PLoS ONE 8(7), e70618 (2013).

36 Xia $\mathrm{T}$, Kovochich M, Liong $\mathrm{M}$ et al. Comparison of the mechanism of toxicity of zinc oxide and cerium oxide nanoparticles based on dissolution and oxidative stress properties. ACS Nano 2(10), 2121-2134 (2008).

37 Samet JM, Graves LM, Quay J et al. Activation of MAPKs in human bronchial epithelial cells exposed to metals. Am. J. Physiol. Lung Cell Mol. Physiol. 275(3), L551-L558 (1998).

38 Simón-Vázquez R, Lozano-Fernández T, PeleteiroOlmedo M, González-Fernández Á. Conformational changes in human plasma proteins induced by metal oxide nanoparticles. Colloids Surf. B. Biointerfaces 113, 198-206 (2014).

39 Vandebriel RJ, De Jong WH. A review of mammalian toxicity of $\mathrm{ZnO}$ nanoparticles. Nanotechnol. Sci. Appl. 5 , 61-71 (2012).

40 Chiao PJ, Miyamoto S, Verma IM. Autoregulation of I kappa B alpha activity. Proc. Natl Acad. Sci. USA 91(1), 28-32 (1994).

41 Brown JJL. Zinc fume fever. Br. J. Radiol. 61(724), 327-329 (1988). 
42 Schwarz Y, Kivity S, Fischbein A et al. Evaluation of workers exposed to dust containing hard metals and aluminum oxide. Am. J. Ind. Med. 34(2), 177-182 (1998).

43 Lozano-Fernández T, Ballester-Antxordoki L, PérezTemprano $\mathrm{N}$ et al. Potential impact of metal oxide nanoparticles on the immune system: the role of integrins, L-selectin and the chemokine receptor CXCR4. Nanomed. Nanotechnol. Biol. Med. 10(6), 1301-1310 (2014). 